\title{
THE PLATONIST PHILOSOPHER ALEXANDER OF LYCOPOLIS ON MANICHAEISM
}

\author{
JOHANNES VAN OORT \\ UNIVERSITY OF NIJMEGEN \\ Johannes van Oort is also a Research Fellow with the \\ Department of New Testament Studies, University of Pretoria.
}

\begin{abstract}
The article starts by describing the present state of research on Alexander of Lycopolis (Egypt), who formerly was considered to be a Christian bishop converted from Manichaeism to orthodox Christianity, but now is generally regarded as a pagan philosopher. After the main contents of his treatise 'Against the Doctrines of Mani' have been outlined, the focus is first on Alexander's unique description of Manichaeism as a form of Christianity and after that on Alexander's own philosophical position.
\end{abstract}

Keywords: Alexander of Lycopolis, Manichaean Christianity, Platonism, Patristics

\section{THE STATE OF RESEARCH ON ALEXANDER}

The place of Alexander in history is based on one single writing. According to the text of this writing transmitted by a late ninth to early tenth century codex from the

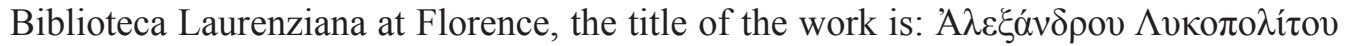

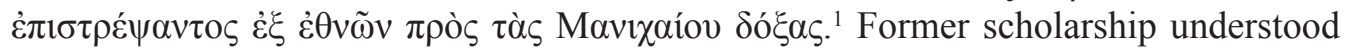
this title as referring to the treatise of a certain Alexander, bishop of Lycopolis, who once 'turned from paganism to the Manichaean opinions. ${ }^{2}$ Modern research, following August Brinkmann in his critical edition with long Praefatio, did not subscribe to this opinion. Alexander was neither converted to Manichaeism, nor was he a Christian bishop. Such false views, presently still circulating by means of the preface to JacquesPaul Migne's often reprinted text edition, ${ }^{3}$ seem to have been caused both by the 
reference of the Byzantine Patriarch Photius (c. 810-c. 890) in his famous Bibliotheca and by the mistaken translation of the manuscript's title by the first editor François Combefis as 'Alexandri Lycopolitae, qui ex gentibus ad Manichaei opiniones conversus

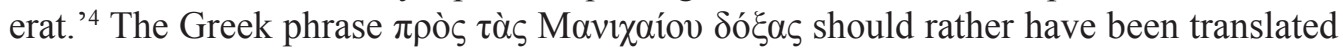
as 'contra Manichaei opinions,' whereas $\dot{\varepsilon} \pi \imath \tau \rho \dot{\varepsilon} \psi \alpha \nu \tau o \zeta \dot{\varepsilon} \xi \dot{\varepsilon} \theta v \tilde{o v}$ simply is a pious invention. Already the founding father of Manichaean studies, the famous Huguenot Isaac de Beausobre (1659-1738), opined that Alexander could only have been 'un Philosophe Payen': (1) in his dispute with the Manichaeans he never quotes from the Bible; (2) he speaks of the souls of the nymphs: 'cela n'est pas du stile Chrétien'; (3) he makes mention of the cataclysms in the age of Deucalion and Phoroneus, but not in Noah's time; (4) he says that 'of all the gods' the Manichaeans only revere the sun and the moon; (5) Greek mythology is considered to be 'our tradition' and the battle of the giants to belong to 'our poetry.' ${ }^{5}$ For these reasons, all leading modern researchers share this opinion and consider Alexander a pagan philosopher. ${ }^{6}$

\section{MAIN CONTENTS OF ALEXANDER'S TREATISE AND ITS IMPORTANCE}

In his treatise Alexander reports that 'some of those who have pursued the study of

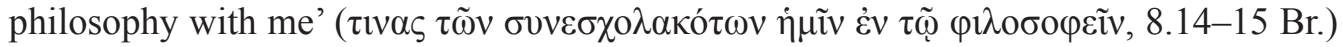
converted to Manichaeism. This refers either to former colleagues during his student years in Alexandria, or (most likely) to some of his own pupils in Lycopolis. The general tone of his writing, as well as Alexander's concern for 'the minds of those who uncritically accept' the Manichaean doctrines (8.12-13), reveal the attitude of the solicitous professor rather than that of the former student. ${ }^{7}$ The circumstances that gave rise to his tract seem to parallel those of the famous Neoplatonist philosopher Plotinus (c. 205-270) of Rome - circumstances that brought about Enneads II.9 'Against the Gnostics. ${ }^{8}$ On a certain day Manichaean missionaries entered Alexander's school in Lycopolis and, under the guise of being his students, started their mission. Alexander mentions some of their names: 'the first expounder of his [Mani's] doctrines to visit us was a man called Papos, after whom came Thomas' (4.17-19). Both are well known from Manichaean texts ${ }^{9}$ and figure in the Coptic Psalmbook which, like other Manichaean texts from Egyptian Medinet Madi, was written in a Coptic dialect typical only of the Lycopolis region. ${ }^{10}$

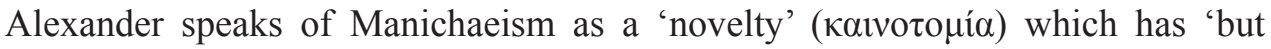
recently' (ov̉ $\pi \alpha \dot{\lambda} \lambda \alpha$ ) come to the fore (4.16-17). Other sources reveal that Manichaeism entered Egypt from 244 onwards. ${ }^{11}$ In 4.21-22 Alexander indicates that he had learnt of the death of Mani (277 or 276), but he does not make mention of Diocletianus' edict against the Manichaeans of the year 297 (or 302). Most probably his treatise, in which a philosopher addresses other philosophers, was written sometime between 277 and 297.

In modern research, Alexander's Against the Doctrines of Manichaios is important for two main reasons. Firstly, because it is a highly significant source for our knowledge of 
early Manichaeism. A main characteristic of Alexander's description is that he considers it to be a form of Christianity. In the past decades, this assessment of Mani's religion has been confirmed by several discoveries of Manichaean texts. ${ }^{12}$ Secondly, because Alexander shows himself to be a Platonist philosopher, his treatise is an important and, in many respects, unique text in the history of early Neoplatonism.

The work can be divided in three main sections: Introduction (on the Christian philosophy and its decadence) (3.1-4.13); Manichaeism (4.13-9.16); Refutation of Manichaeism (9.17-40.6). A closer look at its contents makes clear that it provides an introduction to Manichaeism and methodological considerations on how to refute it (3.1-9.17) and, after that, consists of the philosophical refutation proper (9.17-40.6).

\section{ALEXANDER ON MANICHAEISM AND ITS MAIN TENETS}

Some major elements of the treatise may be highlighted, first and foremost with regard to Manichaeism and Alexander's methodological considerations. To Alexander, Manichaeism is a recent and very deviant form of Christian philosophy. His treatise opens with the apodictic statement: 'The philosophy of the Christians is termed simple' (3.1). Having indicated this simplicity, and also the fact that Christianity focuses on ethical instruction suited for 'ordinary people' (3.1-18), Alexander explains that 'this simple philosophy has been split up into numerous factions' (3.19-20). Some adherents had become leaders of 'sects,' but none of them were able to attain theoretical precision and thus they brought this philosophy to a near nullity (3.20-4.13). The person called Manichaios is an example of this.

Alexander briefly introduces Mani and makes mention of some disciples (4.1322). He then provides a very significant doxography of Manichaeism. This synopsis of Manichaean doctrines is thoroughly marked by his philosophical point of view. It is hard to say whether or not Alexander used a written document. ${ }^{13}$ But what he describes as being Mani's tenets turns out to be highly accurate.

According to Alexander, Mani laid down two principles: God and Matter (vi $\lambda \eta)$. However,

he calls matter not that which Plato calls it, which becomes all things when it assumes quality and shape - therefore he terms it "all-receiving" (Tim. 51a7) and "mother" (Tim. 50d3) and "nurse" (Tim. 49a6) - nor what Aristotle calls it, namely as the element in relation to which form and privation occur (Phys. 190b17-191a22; Metaph. 1069b32, 1070b18-19), but something

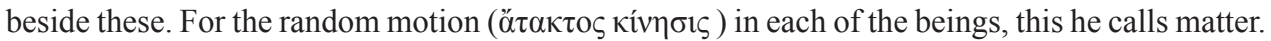
(Brinkmann 5.3-8)

Right from the start Alexander tackles a central Manichaean tenet and, in the course of his refutation, he more than once returns to it $(10.5 .24 ; 11.2 .10-11 ; 23.19 ; 25.21 ; 26.1 .4$; cf. 33.15).

In former years there was much debate between the Orientalist Hans Heinrich Schaeder and the classical philologist Richard Reitzenstein on whether the Greek 


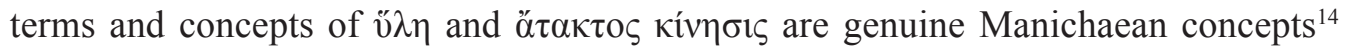
or whether they originated with Alexander or some Neoplatonically-coloured Manichaean source used by him. ${ }^{15}$ In fact it is reasonable to assume that in the sentence quoted above the references to Plato and Aristotle are due to Alexander. One may also assume that in his discussion of these concepts in e.g. 10.4-12 Alexander mixes up his refutation of Mani with his refutation of Middle Platonic concepts of matter such as found in Plutarch, Atticus and Numenius. But from several Manichaean texts and other first-hand testimonies we know for sure that Mani himself termed matter with the

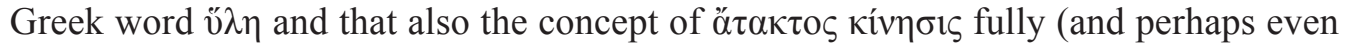
literally) matches the essential character of Manichaean matter. ${ }^{16}$ It is unnecessary to assume the existence of any special written document in order to acquaint Alexander with real Manichaean doctrine: the Manichaean interlocutors in his school would have been his real source.

From these intermediaries Alexander also seems to have received information on many other Manichaean tenets, which he conveys very accurately. What is striking in his account is the (near-) absence of typical Manichaean mythological elements, a feature which might already be due to his interlocutors. In a precise way Alexander discusses Mani's teachings on the two Principles ( $\alpha \rho \chi \alpha i)$ of God and matter; the auxiliary powers on the side of God and those on the side of matter; the desirous attack of matter on 'the region above'; God's sending of 'a certain Power which we call Soul' ( $\psi v \chi \eta$ ); God's sending of a second Power 'which we call Demiurge' ( $\Delta \eta \mu$ tovpyós); the Demiurge's creation of this world from the mixture of Soul and matter; the work of 'another Power' (termed in other sources the Third Envoy or Tertius Legatus) who enables sun and moon to fulfill their task in the delivery of Light; the creation of man as a mixture of matter and divine Soul; Christ as an Intellect (Noṽs); etc. All these teachings, according to the Manichaeans based upon 'the voice of the prophets' and put forward by them 'without any form of proof,' Alexander proposes to answer, with God's help, 'in a rational way'

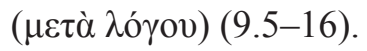

\section{IN SEARCH OF ALEXANDER'S PHILOSOPHY}

It is evident that Alexander's refutation of Mani is coloured by his philosophical system. But what kind of philosophy are we dealing with? In order to get the right perspective on his description and refutation of Manichaeism, this question should be answered first. Throughout the tractate it becomes clear that Alexander is a Platonist. Moreover, he turns out to be a Platonist of an eclectic type. In particular Jaap Mansfeld has described him as an eminent source for the history of Neoplatonism and its Alexandrian variety. In many respects he seems to reveal doctrines which may be attributed to Ammonios Sakkas. ${ }^{17}$

Because the exact doctrines of this founding father of Neoplatonism are unknown, there is an element of speculation in this view. Besides, we do not know that Alexander studied with him. All we have is one accidental writing that fails to provide a systematic 
overview of Alexander's philosophy, but that aims to show the incompatibility of Manichaeism with the essentials of the major currents of Greek philosophy. In order to refute this 'most astonishing doctrine' (cf. 4.15), Alexander brings together arguments from all the important philosophical schools. His refutation of Mani's dualism, for instance, is achieved by referencing a dualistic concept ascribed to the Pythagoreans (10.12-19), but this does not necessarily mean that he himself adheres to such a view.

Yet there is a number of philosophical principles explicitly endorsed by Alexander. Once he speaks of 'the true doctrine' (24.19: $\dot{\eta} \dot{\alpha} \lambda \eta \theta \dot{\eta} \delta$ 'ó $\xi \alpha$; cf. $\tau$ ò $\alpha \lambda \eta \theta \dot{\varepsilon} \varsigma$ 38.5) and sometimes he makes clear that one theory is to be preferred over another (9.17-10.5; cf. 35.14). According to Alexander, there is one first Principle, the cause of all beings.

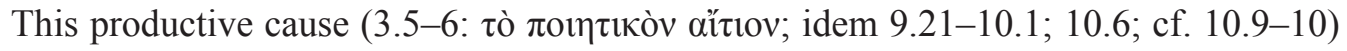
is an Intellect (Noṽs) from which all things come into being hypostatically (10.3-4).

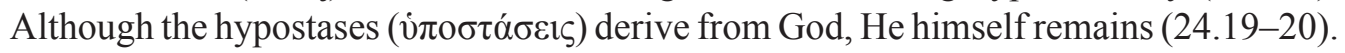

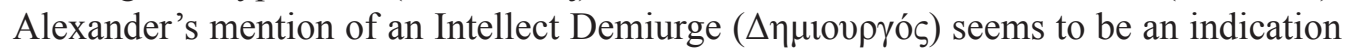
of his pre-Plotinian Platonism. But elsewhere he speaks of God as 'beyond being' ( $\tau$ òv $\dot{\varepsilon} \pi \varepsilon ́ \kappa \varepsilon i v \alpha$ ov̉oías 39.18), which first reminds of Plato's Idea of the Good (Resp. 509b), but also of Plotinus.

Because of his straightforward rejection of Manichaean dualism, and also because of his view of matter, Alexander turns out to be closely connected to Neoplatonic opinions. All this enables him to reject Mani, but also compels him to attack Platonic dualists such as Plutarch, Atticus and Numenius - although their names are not mentioned who taught of primordial matter (cf. 10.2: 'God does not stand in need of matter in order to make things'). Alexander seems to support the idea of a creation of matter by God and out of Himself, an idea which was first taught in Pythagorean circles but is also found elsewhere. ${ }^{18}$ There are strong similarities between Alexander and the fifth century Neoplatonist Hierocles of Alexandria, who considered God to be a demiurgic Intellect whose will was sufficient to cause the hypostasis of all things. ${ }^{19}$ (That this view of Hierocles was due to Christian influences, as was once stated by Praechter, is now definitively rejected by Hadot. $)^{20}$ In Alexander we find this same emphasis on the will of God (39.11-17). This does not imply any movement of God towards the world, but rather some sort of procession of all beings out of the Immovable One: 'those entities which proceed in an orderly way from the divine Immovability are the hypostases' (24.19-20). ${ }^{21}$ Matter, too, seems to have proceeded from God, though perhaps through a hypostasis that was very inferior to the highest Principle. Unfortunately, the polemical character of the treatise hinders us from determining Alexander's position with precision.

The same goes for other subjects essential to the philosophy of his time. From his reaction to the Manichaean doctrine of the soul being mixed up with matter we may deduce his view that there is a World Soul from which all individual souls derive (30.14-17). In contrast to Manichaeism, Alexander stresses that the World Soul cannot leave its body (25.11ff.). Against Mani he also stresses that the coming of the Soul into matter is not a bad thing, but a positive one, since it changes the random motion 


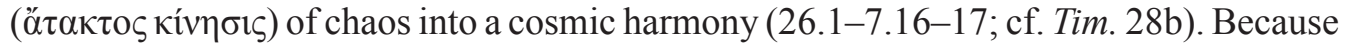
Alexander elsewhere states that the Soul has been connected with matter 'eternally' (25.4), he seems to interpret Plato's Timaeus 28b as relating to an eternal world. Since the Soul both came from the divine Intellect and was made from matter that did not contain any malignancy in and of itself, this world, being eternally reigned by the Soul, is essentially good.

Some other philosophical principles can be gleaned from Alexander's polemical treatise as well. He speaks of intermediate beings between the World Soul and the souls of humans and animals like nymphs and demons (30.15-16). Elsewhere he says that the demons are 'beings endowed with sense-perception' (22.12: $\alpha i \sigma \theta \eta \tau \imath \kappa \alpha ̀ ~ \zeta \tilde{\omega} \alpha)$. Against a supposed Manichaean determinism, which he (incorrectly) interprets in light of Stoic fatalism, Alexander stresses men's free will choice as the only possible source of evil (e.g. 22.21-24). Here, in the writing of a pagan philosopher, we see for the first time what is permanently stressed by all later Greek ecclesiastical writers: the source of evil is men's free will. ${ }^{22}$

In many respects Alexander turns out to be a Platonist, that is, a disciple of a monistic and optimistic interpreted Plato. But, as with other Platonic syncretists, his concept of the first Principle as Intellect is a fusion of the Demiurge of the Timaeus (the Nous contemplating the Ideas) and Aristotle's Intelligence 'intelligizing' itself

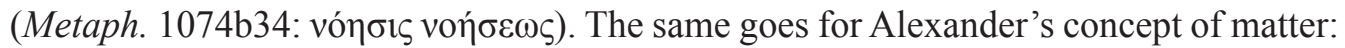
with Plato it is called 'all-receiving,' 'mother' and 'nurse' of all becoming things (5.5; cf. 11.2), and with Aristotle 'the first substratum and that which is without structure'

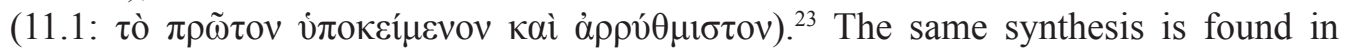
Plotinus and, earlier, in Alkinoos. ${ }^{24}$ But Alexander, in order to refute Mani's doctrine of two antithetical principles, recurrently uses Aristotle's Physica and its theory of the 'proper places' of things (11.18-24; 13.20-14.12; 14.18-15.18). Like Aristotle, he also distinguishes between several kinds of motion (10.23-13.2).

All in all, in his reaction to Manichaean dualism, Alexander turns out to be a Platonist. In this school his position is somewhere between Middle Platonism and Neoplatonism. As in Middle Platonism, his highest Principle seems to be a demiurgic Intellect. But, as is the case with Hierocles, this idea does not seem to be caused by any Christian influence. Alexander's explicit monism and theory of hypostases are signs of a developing Neoplatonism. Perhaps it is best to characterize him as a pre-Plotinian Neoplatonist. Above all, the still rather enigmatic pagan philosopher Alexander, whose work seems to have been preserved because he was supposed to be a Christian bishop, is the very first to set out a line of thought which so many a church father, basing himself on much the same basic principles of philosophical thinking, would follow. 


\section{NOTES}

1 Augustus Brinkmann, ed., Alexandri Lycopolitani contra Manichaei opiniones disputatio (1895; repr., Stutgardiae: B.G. Teubner, 1989), IV-V.

2 James B. H. Hawkins, trans., "Treatise of Alexander, Bishop of Lycopolis, On the Tenets of the Manichaeans: Alexander of Lycopolis, who turned from Paganism to the Manichaean Opinions," in Ante- Nicene Library, vol. XIV (Edinburgh: T\&T Clark, 1869), 236; James B. H. Hawkins, trans., "Alexander, On the Manichaeans," ANF VI (Grand Rapids: Eerdmans, 1978; and all later reprints), 241 n. 1; cf. A. Cleveland Coxe, "Elucidation," ANF VI (Grand Rapids: Eerdmans, 1978; and all later reprints), 252-53.

3 Jacques-Paul Migne, Patrologiae Cursus completus ..., Series Graeca (1857; repr., Turnhout: Brepols Publishers, s.a.), 410-11.

4 Brinkmann, Alexandri Lycopolitani, XXX-XXXI; André Villey, Alexandre de Lycopolis, Contre la doctrine de Mani (Paris: Les Éditions du Cerf, 1985), 13ff.

5 Isaac de Beausobre, Histoire Critique de Manichée et du Manichéisme, I (1734; repr. New York and London: Garland Publishing, 1984), 236-37.

6 Villey, Alexandre de Lycopolis, 16ff.; P.W. van der Horst and J. Mansfeld, trans. with introduction and notes, An Alexandrian Platonist against Dualism. Alexander of Lycopolis' Treatise 'Critique of the Doctrines of Manichaeus' (Leiden: E. J. Brill, 1974); Mark J. Edwards, “A Christian Addition to Alexander of Lycopolis," Mnemosyne 42 (1989): 483-87.

7 Villey, Alexandre de Lycopolis, 198.

8 For which see now Jean-Marc Narbonne, Plotinus in Dialogue with the Gnostics (Leiden: Brill, 2011).

9 Villey, Alexandre de Lycopolis, 108-15; cf. Samuel N. C. Lieu, Manichaeism in the Later Roman Empire and Medieval China (Tübingen: J.C.B. Mohr, 1992), e.g. 90, 103.

10 Charles Allberry, ed. and trans., A Manichaean Psalm-Book, Part II (Stuttgart: Kohlhammer, 1938), e.g. p. 34 for 'Pappos' and pp. 203-28 for 'Psalms of Thomas.'

11 E.g. Iain Gardner and Samuel N. C. Lieu, Manichaean Texts from the Roman Empire (Cambridge: Cambridge University Press, 2004), 111-12.

12 See e.g. J. van Oort et al., eds., Augustine and Manichaeism in the Latin West (Leiden: Brill, 2012), passim; idem ed., Augustine and Manichaean Christianity (Acts of the First South African Conference on Augustine of Hippo. University of Pretoria, 24-26 April 2012 [Leiden: Brill, 2013, forthcoming]), passim.

13 See Hans Heinrich Schaeder, "Urform und Fortbildungen des manichäischen Systems," in Vorträge der Bibliothek Warburg, Vorträge 1924/25 (Leipzig: B. G. Teubner, 1927), 65-157; repr. in Hans Heinrich Schaeder, Studien zur orientalischen Religionsgeschichte (Darmstadt: Wissenschaftliche Buchgesellschaft, 1968). Schaeder made much of $\varphi \eta \mu \eta$ in 4.23-24: 'The account ( $\varphi \eta \mu \eta)$ of this man's doctrine as it came down to us by his pupils.'

14 Schaeder, "Urform und Fortbildungen."

15 Richard Reitzenstein, Die Vorgeschichte der christlichen Taufe (1929; repr. Darmstadt: Wissenschaftliche Buchgesellschaft, 1967), 92-93; Richard Reitzenstein, “Alexander von Lykopolis," Philologus 86 (1931a): 185-98; Richard Reitzenstein, "Eine wertlose und eine wertvolle Überlieferung über den Manichäismus," in Nachrichten von der Gesellschaft der Wissenschaften zu Göttingen: Philologisch-historische Klasse (Göttingen, 1931), 28-58; cf. 


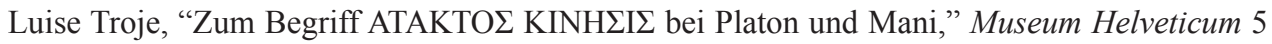
(1948): 96-115.

16 Johannes van Oort, "Augustine and Mani on concupiscentia sexualis," in Augustiniana Traiectina. Communications présentées au Colloque International d'Utrecht, 13-14 novembre 1986 (ed. J. van Oort and J. den Boeft; Paris: Études Augustiniennes, 1987), 140-45.

17 Mansfeld in Van der Horst and Mansfeld, An Alexandrian Platonist, e.g. 6-46.

18 Mansfeld in Van der Horst and Mansfeld, An Alexandrian Platonist, 14ff.

19 Cf. Mansfeld in Van der Horst and Mansfeld, An Alexandrian Platonist, 25-26.

20 Karl Praechter, "Christlich-neuplatonische Beziehungen," Byzantinische Zeitschrift 21 (1912): 1-27; Ilsetraut Hadot, "Le démiurge comme principe dérivé dans le système ontologique d'Hiéroclès," Revue des Études Grecques 103 (1990): 241-62.

21 Cf. Villey, Alexandre de Lycopolis, 77.282.

22 Cf. e.g. Wolfgang Wassilios Klein, Die Argumentation in den griechisch-christlichen Antimanichaica (Wiesbaden: Otto Harrassowitz, 1991), esp. 113-32: 'Die christliche Erklärung des Bösen in der Welt.'

23 Cf. Mansfeld in Van der Horst and Mansfeld, An Alexandrian Platonist, 62-63 nn. 234-35.

24 Cf. Villey, Alexandre de Lycopolis, 220-22.

\section{BIBLIOGRAPHY}

Allberry, Charles, ed. and trans. A Manichaean Psalm-Book. Part II, Manichaean Manuscripts in the Chester Beatty Collection, 2. Stuttgart: Kohlhammer, 1938.

Brinkmann, Augustus, ed. Alexandri Lycopolitani contra Manichaei opiniones disputatio. Leipzig: B.G. Teubner, 1895. Reprint, Stutgardiae: B.G. Teubner, 1989.

Coxe, A. Cleveland. "Elucidation" [sc. on Alexander of Lycopolis]. Pages 252-53 in The Ante-Nicene Fathers VI. Grand Rapids: Eerdmans, 1978.

De Beausobre, Isaac. Histoire Critique de Manichée et du Manichéisme. [Tome Premier], A Amsterdam, Chez J. Frédéric Bernard MDCCXXXIV. Reprint, New York \& London: Garland Publishing, 1984.

Edwards, Mark J. “A Christian Addition to Alexander of Lycopolis.” Mnemosyne 42 (1989): 483-87.

Gardner, Iain, and Samuel N. C. Lieu. Manichaean Texts from the Roman Empire. Cambridge: Cambridge University Press, 2004.

Hadot, Ilsetraut. "Le démiurge comme principe dérivé dans le système ontologique d'Hiéroclès." Revue des Études Grecques 103 (1990): 241-62.

Hawkins, James B. H., trans. "Treatise of Alexander, Bishop of Lycopolis, On the Tenets of the Manichaeans: Alexander of Lycopolis, who turned from Paganism to the Manichaean Opinions." Pages 231-66 in Ante-Nicene Library. Vol. XIV. Edinburgh: T\&T Clark, 1869.

Hawkins, James B. H., trans. "Alexander, On the Manichaeans." Pages 237-52 in The Ante-Nicene Fathers VI. Grand Rapids: Eerdmans, 1978.

Klein, Wolfgang Wassilios. Die Argumentation in den griechisch-christlichen Antimanichaica. Vol. 19 of Studies in Oriental Religions. Wiesbaden: Otto Harrassowitz, 1991. 
Lieu, Samuel N. C. Manichaeism in the Later Roman Empire and Medieval China. Tübingen: J.C.B. Mohr (Paul Siebeck), 1992.

Migne, Jacques-Paul. Patrologiae Cursus completus, Series Graeca accurante J.-P. Migne, tomus XVIII, [Parisii] Excudebatur et venit apud J.-P. Migne Editores, 1857. Reprint, Turnhout: Brepols Publishers, s.a., 411-47.

Narbonne, Jean-Marc. Plotinus in Dialogue with the Gnostics. Leiden: Brill, 2011.

Praechter, Karl. "Christlich-neuplatonische Beziehungen.” Byzantinische Zeitschrift 21 (1912): 1-27.

Reitzenstein, Richard. Die Vorgeschichte der christlichen Taufe. Leipzig-Berlin: B.G. Teubner, 1929. Reprint, Darmstadt: Wissenschaftliche Buchgesellschaft, 1967.

Reitzenstein, Richard. “Alexander von Lykopolis.” Philologus 86 (1931a): 185-98.

Reitzenstein, Richard. "Eine wertlose und eine wertvolle Überlieferung über den Manichäismus." Pages 28-58 in Nachrichten von der Gesellschaft der Wissenschaften zu Göttingen: Philologischhistorische Klasse. Göttingen, 1931.

Schaeder, Hans Heinrich. "Urform und Fortbildungen des manichäischen Systems." Pages 65-157 in Vorträge der Bibliothek Warburg, Vorträge 1924/25. Leipzig: B.G. Teubner, 1927. Reprint in Hans Heinrich Schaeder, Studien zur orientalischen Religionsgeschichte. Darmstadt: Wissenschaftliche Buchgesellschaft, 1968.

Troje, Luise. "Zum Begriff ATAKTO $\mathrm{KINH} \Sigma \mathrm{I} \Sigma$ bei Platon und Mani." Museum Helveticum 5 (1948): 96-115.

Van der Horst, P. W. and J. Mansfeld, trans. with introduction and notes. An Alexandrian Platonist against Dualism. Alexander of Lycopolis' Treatise 'Critique of the Doctrines of Manichaeus.' Leiden: E. J. Brill, 1974.

Van Oort, Johannes. "Augustine and Mani on concupiscentia sexualis." Pages 137-52 in Augustiniana Traiectina. Communications présentées au Colloque International d'Utrecht, 13-14 Novembre 1986. Edited by J. van Oort and J. den Boeft. Paris: Études Augustiniennes, 1987.

Van Oort, Johannes et al. eds. Augustine and Manichaeism in the Latin West. Leiden: Brill, 2012.

Van Oort, Johannes, ed. Augustine and Manichaean Christianity. Acts of the First South African Conference on Augustine of Hippo. University of Pretoria, 24-26 April 2012. Leiden: Brill, forthcoming.

Villey, André, trans. and comm. Alexandre de Lycopolis, Contre la doctrine de Mani. Paris: Les Éditions du Cerf, 1985. 